UDC 616.1:616.831-005.1-02:616.12-008.331.1-06;

DOI 10.32345/USMYJ.3(125).2021.32-43

\title{
EVALUATION OF CARDIOVASCULAR DYSREGULATION IN PATIENTS AFTER HEMORRHAGIC STROKE AS A COMPLICATION OF ESSENTIAL HYPERTENSION
}

\author{
Tkachyshyn Oleksandr \\ Assistant professor of the Department of propedeutics of internal medicine №1 Bogomolets \\ National Medical University, Department of propedeutics of internal medicine №1 Kyiv, \\ Ukraine,
}

\begin{abstract}
The aim of the study was to compare blood pressure and electrocardiogram indices, assessed by their daily monitoring, and anamnestic data on mild traumatic brain injury between a group of patients with essential hypertension $\geq 6$ months after a hemorrhagic stroke and a group of patients with essential hypertension without complications. Materials and methods. The total number of examined patients was 198 people, who were divided into 2 groups: the main ( $=94$; age - 54,4 $\pm 8,8$ years, $M \pm \sigma$ years) and the control ( $n=104$; age $-53,7 \pm 8,9$ years) one. Patients in the main group suffered a hemorrhagic stroke as a complication of essential hypertension $\geq 6$ months ago. The control group included patients with essential hypertension, stage II. In both groups of patients, the parameters of 24-hour ambulatory blood pressure monitoring and electrocardiogram were determined. Results. The indices of 24-hour ambulatory blood pressure monitoring in the main group and the control group were the following ones, respectively: the mean daytime systolic blood pressure was 109,6 1,6 and

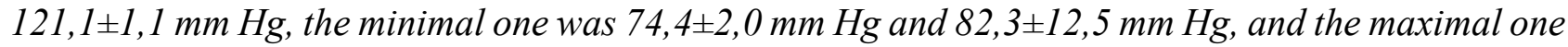
was $168,2 \pm 1,9$ and $161,9 \pm 1,7 \mathrm{~mm} \mathrm{Hg}, p<0,05$. The daytime sigma systolic blood pressure $(17,9 \pm 0,6)$ and its average real variability of $(11,31 \pm 2,52 \mathrm{~mm} \mathrm{Hg})$ were bigger in the main group $(p<0,05)$. The daytime index of the hyperbaric load of systolic blood pressure was bigger in the main group: it was 403,6 $\pm 25,9$ against 231,7 $\pm 12,1 \mathrm{~mm} \mathrm{Hg} \times \mathrm{h}$ in the comparison group $(p<0,05)$. The mean, minimum and maximum heart rate at night were significantly lower in the main group $(p<0,05)$. The QTc ${ }_{\text {min }}$

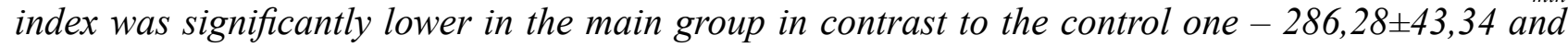
$336,69 \pm 22,55$, and the $Q T$ variance was greater - 232,56 444,55 - in comparison to the control group $(188,31 \pm 33,67)(p<0,05)$. From the anamnestic data of patients, a significantly higher prevalence of mild traumatic brain injury was found in 37,4\% (35 patients out of 94) in the main group relative to the control one $-13,5 \%$ (14 out of 104), $p<0,05$. Conclusions: The results of the study indicate the larger ranges of blood pressure variability in patients with essential hypertension complicated with hemorrhagic stroke, which can be caused by impaired autoregulation according to the QTc interval data. In combination with the disturbances of cerebral circulation, caused by the injury of the brain due to the hemorrhagic stroke alone or in combination with mild traumatic brain injury episode, such a situation may lead to the development of recurrent stroke.
\end{abstract}

Keywords: hemorrhagic stroke, essential hypertension, blood pressure monitoring, electrocardiograms, mild traumatic brain injury.

Introduction. There is evidence that an increase in blood pressure (BP) by $20 / 10 \mathrm{~mm} \mathrm{Hg}$ doubles the risk of cardiovascular complications (Unifikovany`j klinichny`j protokol ..., 2014). Essential hypertension (EH), especially grade 3 (with $\mathrm{BP} \geq 180 / 100 \mathrm{~mm} \mathrm{Hg}$ ), as well as EH complicated with hypertensive crises (Zozulya and Kit, 2013), is the most common cause of cerebral hemorrhage. The pathogenesis of the latter is based on the failure of autoregulation (Zozulya et 
al., 2015), (Fauci, 2015). It should be noted that autoregulation of the brain allows for maintaining almost constant cerebral perfusion pressure at different levels of systemic BP, protecting it from changes in sympathetic nervous activity (Clausen et al., 2015). The autoregulation involves active changes in vascular resistance to maintain a constant blood flow in a relatively wide range of average $\mathrm{BP}$ - usually 50-150 $\mathrm{mm} \mathrm{Hg}$ (Avolio et al., 2018). The mechanisms in which the central nervous system is involved begin are activated immediately after the onset of receptor excitation. They serve as continuously functioning buffer and designed mainly to minimize BP fluctuations when changing body posture, at psycho-emotional and physical stress, i.e. adapt the body's cardiovascular system to constantly changing environmental conditions (Vizir et al., 2018).

It is a well-known fact that cerebral circulation autoregulation is impaired after a hemorrhagic stroke (Koide et al., 2021), (Jaeger et al., 2012), (Ma et al., 2017). In addition, it is important to note the late effect of traumatic brain injury (TBI) on cerebral autoregulation (Glushko and Ly`tvy`nenko, 2016), such as excessive changes in cerebral perfusion pressure after concussion.

Clausen M. et al. showed that patients after the TBI have abnormally elevated BP at lower levels of exercise on the treadmill test (Clausen et al., 2015). Hence, mild TBI in past medical history of patients with hemorrhagic stroke may indicate a probable background of cerebrovascular dysfunction. Therefore, 24-hour blood pressure monitoring (24-h BPM) may reveal a tendency to increased BP lability in these patients and reveal its autonomous control disorders.

The autonomic nervous system dysfunction may also contribute to mortality increase in patients with a history of mild TBI. In resting TBI patients with neither persistent neurological deficits nor clinically significant autonomic dysfunction, a general decrease in autonomic cardiovascular modulation with a shift to a greater sympathetic tone and less parasympathetic cardiovascular control was found, as well as a decrease in baroreflex sensitivity (Audrey and Procter, 2015). Consequently, the initial state of autoregulation of the vascular network of the brain is hardly less important than the influence of systemic BP itself. Thus, in patients with hemorrhagic stroke, it is important to find out not only BP level but also the presence of autonomic imbalance, which can be assessed, inter alia, by 24-hour ECG monitoring, namely the QT interval and its variance (Kovalenko, 2008).

The aim of the study was to investigate the possible relevance of 24-hour BP and ECG monitoring data and presence of mild traumatic brain injury in natural history in patients with essential hypertension $\geq 6$ months after a hemorrhagic stroke and patients with essential hypertension without complications.

Methods. The study involved 198 people, who were divided into main and control groups. The main group consisted of patients at least 6 months after hemorrhagic stroke as a complication of $\mathrm{EH}(\mathrm{n}=94)$; at the time of the hemorrhagic stroke they were treated in the clinic of vascular neurosurgery of the State Institution "Romodanov Neurosurgery Institute of the National Academy of Medical Sciences of Ukraine". Criterion of inclusion: EH before the development of hemorrhagic stroke. Only individuals who recovered neurologically up to 50-100 points on the Barthel scale and had BP $\geq 140 / 90 \mathrm{~mm} \mathrm{Hg}$ after the episode of hemorrhagic stroke were selected.

The patients with EH, stage II, but without hemorrhagic stroke in medical history $(n=104)$, were selected for the control group. The characteristics of the study groups are presented in Table 1 .

The examination of patients in the main group was performed once during the follow-up time after the stroke. Mean follow-up was 18,3 $\pm 1,2$ months (from 6 to 51).

The examination of all patients was performed at the clinical sites of the Department of propaedeutics of internal medicine №1 of the Bogomolets National Medical University from November 2016 until July 2018.

24-h BPM and ECG monitoring were performed on a CardioSpy device (Labtech Ltd, Hungary), software version V4.04.RC24, recorder version V1.16. There were three recording periods: daytime (06:00 - 22:00), nighttime (22:00 06:00), and 24 hours. We determined the mean 
value $\left(\mathrm{BP}_{\text {mean }}\right)$, minimum $\left(\mathrm{BP}_{\text {min }}\right)$, and maximum $\left(\mathrm{BP}_{\max }\right)$ values of $\mathrm{BP}$, the difference between the latter two (delta BP), the sigma of the BP values during the recording period, the percentage of time of excess of the upper limit (time index) and the load index (hyperbaric index - HI) (Iimuro et al., 2017), the average real variability (ARV) (Mena et al., 2017). The mean, minimum, maximum values of heart rate (HR) and its sigma, as well as the mean, minimum, and maximum values of the adjusted (corrected) QT interval (QTc) and its variance were determined (Mal'ceva et al., 2014).

The adequacy of the circadian rhythm of BP was assessed by the degree of nocturnal decrease in systolic BP (SBP) and diastolic BP (DBP) - by the daily index (DI) for each of them:

\section{$\mathrm{DI}=\left(\frac{\text { daytime BPmean }- \text { nighttime BPmean }}{\text { daytime BPmean }}\right) \times 100 \%$}

Depending on the BP profile, the subjects with $10-20 \%$ nocturnal SBP ${ }_{\text {mean }}$ decrease (physiological) were defined as "dippers". The subjects who did not reach the level of $10 \%$ decrease were called "non-dippers", the persons who showed a decrease of $\geq 20 \%$ - "over-dippers", the subjects who had a nighttime increase in BP were called "night-peakers" (Baldi et al., 2017).

The data about the presence of mild TBI in anamnesis of the patients were also collected.

The results of the study are presented in the form of $M \pm \sigma$. Statistical processing of the obtained data was performed using IBM SPSS Statistics Base v.22 (Kirkpatrick and Feeney, 2014) (license agreement of the Bogomolets National Medical University with the registration №138 dated 04.08.2016).
The difference between the compared parameters with the normal distribution of the variants was evaluated by Student's t-test, between those who had an abnormal distribution of the variants - by the U-test of Mann-Whitney. The analysis of the obtained results was performed following the generally accepted recommendations (Antomonov, 2017). The difference between the study groups was considered statistically significant when $\mathrm{p}<0,05$.

The study was conducted following the Helsinki Declaration of the World Medical Association "Ethical Principles of Medical Research with Human Participation" (1964, updated in 2000). The patient or his legal representative filled in the Informed Consent (Expert opinion of the Ethics Commission of the Bogomolets National Medical University dated October 26, 2016, protocol №98).

Results. The obtained parameters of SBP and DBP from 24-h BPM in the main and the control groups were analyzed. At the first stage of the analysis, the SBP parameters were identified and compared between the studied groups. The results obtained are presented in Table 2 .

As presented in Table $2 \mathrm{SBP}_{\text {mean }}$ and $\mathrm{SBP}_{\text {min }}$ during the daytime, nighttime, and around the clock (in general) were significantly $(p<0,05)$ lower in the main group in contrast to the control one. The average value of $\mathrm{SBP}_{\text {max }}$ during the daytime was $3,7 \%$ higher, and $\mathrm{SBP}_{\text {max }}$ at nighttime $9,2 \%$ lower in the main group compared to the control one $(p<0,05)$.

Thus, the parameter of delta SBP during the daytime in the main group was $93,1 \pm 34,7 \mathrm{~mm}$

Table 1. Characteristics of patients of the studied groups $(\mathrm{M} \pm \sigma)$

\begin{tabular}{|l|c|c|}
\hline \multicolumn{1}{|c|}{ Parameter } & Main group, $\mathbf{n = 9 4}$ & Control group, $\mathbf{n = 1 0 4}$ \\
\hline Middle age, years & $54,4 \pm 8,8$ & $53,7 \pm 8,9$ \\
\hline Quantity of men & $44(46,8 \%)$ & $50(48,1 \%)$ \\
\hline Concomitant diabetes mellitus, type 2 & $12(12,8 \%)$ & $15(14,4 \%)$ \\
\hline Duration of the period after stroke incidence, months & $18,3 \pm 12,1$ & - \\
\hline Body mass index, $\mathrm{kg} / \mathrm{m} 2$ & $28,67 \pm 4,47$ & $28,97 \pm 4,39$ \\
\hline Office systolic BP, $\mathrm{mm} \mathrm{Hg}$ & $154,3 \pm 7,2$ & $155,2 \pm 7,4$ \\
\hline Office diastolic BP, $\mathrm{mm} \mathrm{Hg}$ & $97,6 \pm 4,6$ & $98,2 \pm 4,8$ \\
\hline
\end{tabular}

* - the difference is significant between similar parameters of the groups $(p<0,05)$. 
Table 2. 24-h BPM SBP parameters $(\mathrm{M} \pm \sigma)$

\begin{tabular}{|c|c|c|c|c|c|c|}
\hline \multirow{2}{*}{ Parameter } & \multicolumn{2}{|c|}{ Daytime } & \multicolumn{2}{c|}{ Nighttime } & \multicolumn{2}{c|}{ 24-h period } \\
\cline { 2 - 7 } & $\begin{array}{c}\text { Main } \\
\text { group, } \mathbf{n}=\mathbf{9 4}\end{array}$ & $\begin{array}{c}\text { Control } \\
\text { group, } \mathbf{n}=\mathbf{1 0 4}\end{array}$ & $\begin{array}{c}\text { Main } \\
\text { group, } \mathbf{n}=\mathbf{9 4}\end{array}$ & $\begin{array}{c}\text { Control } \\
\text { group, } \mathbf{n}=\mathbf{1 0 4}\end{array}$ & $\begin{array}{c}\text { Main } \\
\text { group, } \mathbf{n}=\mathbf{9 4}\end{array}$ & $\begin{array}{c}\text { Control } \\
\text { group, } \mathbf{n}=\mathbf{1 0 4}\end{array}$ \\
\hline $\mathbf{1}$ & $\mathbf{2}$ & $\mathbf{3}$ & $\mathbf{4}$ & $\mathbf{5}$ & $\mathbf{6}$ & $\mathbf{7}$ \\
\hline SBPmax, $\mathrm{mm} \mathrm{Hg}$ & $168,2 \pm 18,1^{*}$ & $161,9 \pm 17,7$ & $125,6 \pm 21,5^{*}$ & $137,1 \pm 18,4$ & $168,3 \pm 18,1$ & $164,5 \pm 17,1$ \\
\hline SBPmin, $\mathrm{mm} \mathrm{Hg}$ & $74,4 \pm 19,5^{*}$ & $82,3 \pm 12,5$ & $79,7 \pm 16,2^{*}$ & $91,2 \pm 12,5$ & $72,0 \pm 18,2^{*}$ & $80,1 \pm 13,0$ \\
\hline Delta SBP, mm Hg & $93,1 \pm 34,7^{*}$ & $79,5 \pm 19,0$ & $45,9 \pm 17,2$ & $45,9 \pm 12,5$ & $96,3 \pm 34,6^{*}$ & $84,4 \pm 22,5$ \\
\hline SBPmean, $\mathrm{mm} \mathrm{Hg}$ & $109,6 \pm 15,8^{*}$ & $121,1 \pm 11,3$ & $101,9 \pm 17,0^{*}$ & $108,3 \pm 14,1$ & $109,6 \pm 15,5^{*}$ & $118,1 \pm 9,7$ \\
\hline SBP sigma & $17,9 \pm 5,9^{*}$ & $15,1 \pm 2,6$ & $13,5 \pm 4,5$ & $12,1 \pm 4,5$ & $17,8 \pm 5,1$ & $16,5 \pm 3,6$ \\
\hline SBP time index, \% & $10,7 \pm 14,1$ & $14,3 \pm 15,4$ & $21,0 \pm 26,8$ & $25,3 \pm 26,8$ & $14,3 \pm 16,8$ & $16,6 \pm 14,0$ \\
\hline SBP HI, mm Hg $\times \mathrm{h}$ & $403,6 \pm 250,9^{*}$ & $231,7 \pm 123,0$ & $185,3 \pm 271,2$ & $220,6 \pm 149,6$ & $384,7 \pm 176,1 *$ & $256,5 \pm 97,2$ \\
\hline
\end{tabular}

$\mathrm{Hg}$ and it was significantly $(\mathrm{p}<0,05)$ larger compared to the control group. The results obtained may indicate a greater range of fluctuations in daytime SBP in patients of the main group. When comparing the delta SBP at nighttime between the main group and the control one, no significant difference was found $(\mathrm{p}>0,05)$. In the main group, the larger amplitude of SBP oscillations prevails only during the daytime, in contrast to the control group. The patients in the main group had pronounced interindividual differences in the value of delta SBP, therefore this value during the daytime was nonparametric ( $\sigma$ was more than $25 \%$ of the mean value)

When analyzing the data on $\mathrm{SBP}_{\text {mean }}$, it was found that at all time intervals - day, night, and around the clock - in the main group this parameter was significantly $(\mathrm{p}<0,05)$ lower by $9,5 \%$, $5,9 \%$ and $7,2 \%$, respectively, compared to the control group.

Sigma SBP during the daytime also showed a significantly $(p<0,05)$ greater difference between the main and control groups of patients. When paralleling similar compared pairs according to the sigma SBP at nighttime, no significant difference was found $(p>0,05)$. To determine the variability prevalence of SBP in the $24-\mathrm{h}$ period in the main group, the parameters of sigma SBP during the daytime $(17,9 \pm 5,9)$ and sigma SBP at nighttime $(13,5 \pm 4,5)$ were compared. There was a statistically significant difference $(p<0,05)$ in the main group between the day and night time sigma SBP revealed. The obtained results indi- cate the largest fluctuations of SBP during the daytime in patients of the main group.

Continuing the study of BP fluctuations, the ARV of SBP in the main group and in the control group was determined. The obtained results are schematically presented in Fig. 1.

Therefore, SBP ARV in the main group was significantly $(p<0,05)$ higher than in the control one, what may indicate a higher risk of any sud-

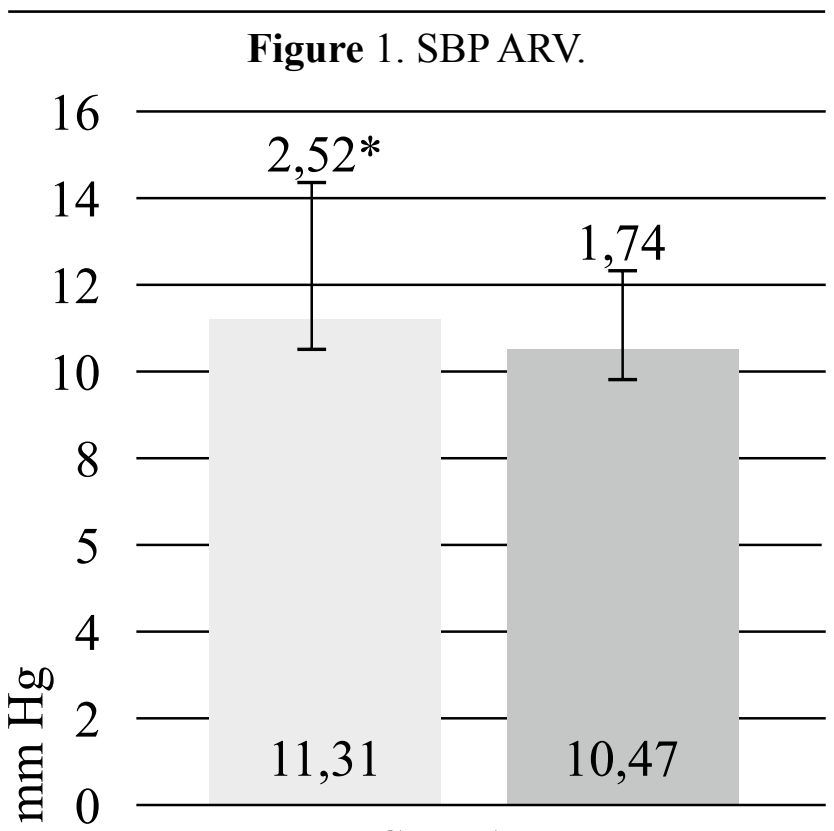

\section{SBP ARV}

Main group, $\mathrm{n}=94$

Control group, $\mathrm{n}=104$

* - the difference is significant between similar parameters of the surveyed groups $(\mathrm{p}<0,05)$. 
den cardiovascular event in EH and death of the patient. Thus, despite the higher absolute values of $\mathrm{SBP}_{\text {mean }}$ in the control group, the difference in SBP between successive measurements in patients of the main group was greater $(p<0,05)$.

Therefore, a wider range of SBP fluctuations prevailed during the daytime in the main group, although $\mathrm{SBP}_{\text {mean }}$ in all these periods was higher in the control group $(p<0,05)$. Such results may indicate that there were short-term rises of SBP with greater amplitude in the main group, which could not be detected in the case of routine office BP measurement, conducted outside of this time window of BP rapid increase. As a result, there may be a false impression of the success in EH control, especially in those patients who do not suffer from the specific symptoms of BP elevation.

Noteworthy, despite the lower $\mathrm{SBP}_{\text {mean }}$ in the main group, the SBP HI during the daytime and $24-h$ period were significantly higher $(p<0,05)$ than such at the appropriate time intervals in the control group. At the same time, as it can be seen from the SBP HI, such short-term rises gave a greater load on the cardiovascular system than a more stable elevated SBP, which was more common for the patients in the control group.

The next stage of the study was to investigate the parameters of DBP. The baseline data of the study groups are presented in Table 3. Despite significantly lower mean and minimum values in the main group in all time intervals $(p<0,05)$, as well as the absence of difference in daytime and 24-h period $\mathrm{DBP}_{\max }$, the hyperbaric load on the cardiovascular system assessed by the DBP HI in patients of the main group was larger than in the control one by $34,4 \%$ and $41,0 \%$ during the daytime and around the clock, respectively $(\mathrm{p}<0,05)$. This result can be explained by significantly larger $(p<0,05)$ values of the DBP sigma and delta DBP during the daytime, but not at nighttime, which led to a significant difference $(p<0,05)$ in these parameters during the $24-\mathrm{h}$ period as well. However, the determination of DBP ARV did not reveal a significant difference between the main and control groups, in which this parameter was $8,35 \pm 1,83$ and $8,07 \pm 1,24$, respectively.

The parameters of the DBP time index in the corresponding comparable time intervals, as in the case of SBP, did not show a significant difference between the study groups. Such data indicate no difference between patients of two groups in the total duration of episodes of elevated SBP and DBP during the three periods of 24-h BPM registration.

It should be noted that the parameters of mean, minimum, and maximum SBP and DBP at nighttime were significantly lower in patients of the main group $(p<0,05)$ than in the control. This may indicate that in the control group there was a more pronounced vasopressor effect at this time.

Summarizing the results obtained by $24-\mathrm{h}$ BPM, one can notice the trend to impaired ability to maintain stable BP in patients of the main group.

Furthermore, the daily BP profile in patients of the main and control group was investigated and presented in Table 4.

Table 3. 24-h BPM DBP parameters $(\mathrm{M} \pm \sigma)$

\begin{tabular}{|c|c|c|c|c|c|c|}
\hline \multirow{2}{*}{ Parameter } & \multicolumn{2}{|c|}{ Daytime } & \multicolumn{2}{c|}{ Nighttime } & \multicolumn{2}{c|}{ 24-h period } \\
\cline { 2 - 7 } & $\begin{array}{c}\text { Main } \\
\text { group, } \mathbf{n = 9 4}\end{array}$ & $\begin{array}{c}\text { Control } \\
\text { group, } \mathbf{n}=\mathbf{1 0 4}\end{array}$ & $\begin{array}{c}\text { Main } \\
\text { group, } \mathbf{n = 9 4}\end{array}$ & $\begin{array}{c}\text { Control } \\
\text { group, } \mathbf{n = 1 0 4}\end{array}$ & $\begin{array}{c}\text { Main } \\
\text { group, } \mathbf{n = 9 4}\end{array}$ & $\begin{array}{c}\text { Control } \\
\text { group, } \mathbf{n = 1 0 4}\end{array}$ \\
\hline $\mathbf{1}$ & $\mathbf{2}$ & $\mathbf{3}$ & $\mathbf{4}$ & $\mathbf{5}$ & $\mathbf{6}$ & $\mathbf{7}$ \\
\hline DBPmax, mm Hg & $117,2 \pm 17,6$ & $114,0 \pm 16,5$ & $82,5 \pm 14,6^{*}$ & $87,5 \pm 9,7$ & $117,9 \pm 17,7$ & $114,1 \pm 16,3$ \\
\hline DBPmin, mm Hg & $43,8 \pm 12,9^{*}$ & $55,5 \pm 12,9$ & $50,5 \pm 13,0^{*}$ & $55,8 \pm 11,1$ & $41,0 \pm 10,8^{*}$ & $51,9 \pm 11,4$ \\
\hline Delta DBP, mm Hg & $73,4 \pm 22,8^{*}$ & $58,5 \pm 15,4$ & $32,0 \pm 9,7$ & $31,7 \pm 6,9$ & $76,9 \pm 22,3^{*}$ & $62,2 \pm 15,8$ \\
\hline DBPmean, mm Hg & $71,1 \pm 10,0^{*}$ & $79,3 \pm 7,6$ & $64,1 \pm 11,2^{*}$ & $67,7 \pm 10,0$ & $70,4 \pm 9,6^{*}$ & $76,6 \pm 6,9$ \\
\hline DBP sigma & $13,5 \pm 3,6^{*}$ & $10,5 \pm 1,7$ & $9,1 \pm 3,0$ & $8,7 \pm 2,5$ & $13,6 \pm 3,2^{*}$ & $11,6 \pm 2,9$ \\
\hline DBP time index, \% & $9,3 \pm 7,6$ & $15,5 \pm 20,2$ & $13,3 \pm 27,6$ & $15,9 \pm 20,5$ & $10,3 \pm 9,7$ & $15,6 \pm 18,7$ \\
\hline DBP HI, mm Hg $\times \mathrm{h}$ & $377,1 \pm 291,1^{*}$ & $221,3 \pm 127,6$ & $132,8 \pm 178,1$ & $139,0 \pm 111,6$ & $376,4 \pm 292,3^{*}$ & $218,4 \pm 100,4$ \\
\hline
\end{tabular}

* - the difference is significant between similar parameters of the surveyed groups $(\mathrm{p}<0,05)$. 
Table 4. DI of BP in the study groups $(\mathrm{M} \pm \sigma)$

\begin{tabular}{|c|c|c|}
\hline Parameter & Main group, $\mathbf{n = 9 4}$ & Control group, $\mathbf{n}=\mathbf{1 0 4}$ \\
\hline SBP DI, \% & $5,03 \pm 9,42 *$ & $11,02 \pm 6,71$ \\
\hline DBP DI, \% & $9,51 \pm 8,97 *$ & $10,64 \pm 6,33$ \\
\hline
\end{tabular}

According to the results of Table 4, the daily BP profile in patients who suffered from hemorrhagic stroke and had elevated BP varied significantly, and therefore there was a need for rational antihypertensive treatment. A distribution of patients of the main and control groups according to the daily BP profile is presented in Fig. 2.

In the main group, there were significantly $(p<0,05)$ fewer people with the BP profile "over-dipper" and significantly $(p<0,05)$ more ones with "non-dipper" compared to the control group. These results can be explained by the fact that SB$\mathrm{P}_{\text {mean }}$ in the main group decreased less at nighttime compared to the daytime period (from 109,6 $\pm 15,8$ to $101,9 \pm 17,0 \mathrm{~mm} \mathrm{Hg}$ ) in contrast to the control group (from 121,1 $\pm 11,3$ to $108,3 \pm 14,1 \mathrm{~mm} \mathrm{Hg}$ ).

In the category of "night-peaker", the percentage of patients from the main group was higher than in the control group, although the difference did not reach a statistically significant level $(\mathrm{p}>0,05)$.

In the analysis of 24-h BPM, the attention was paid not only to BP but also to HR to get a more complete picture of hemodynamics. In this regard, the analysis of the following parameters was performed: $\mathrm{HR}_{\text {mean }}, \mathrm{HR}_{\text {min }}, \mathrm{HR}_{\text {max }}$ and $\mathrm{HR}$ sigma during the daytime, nighttime, and around the clock. The data are presented in Table 5.

From Table 5 it is seen that the studied groups differed only in the nocturnal parameters of mean, minimum and maximum HR, which are significantly $(p<0,05)$ lower in the main group compared to the similar parameters in the control one. This may indicate the increased activity of the parasympathetic nervous system to compensate for the periodic excess exposure of the sym-

Figure 2. Distribution of patients by daily BP profile.

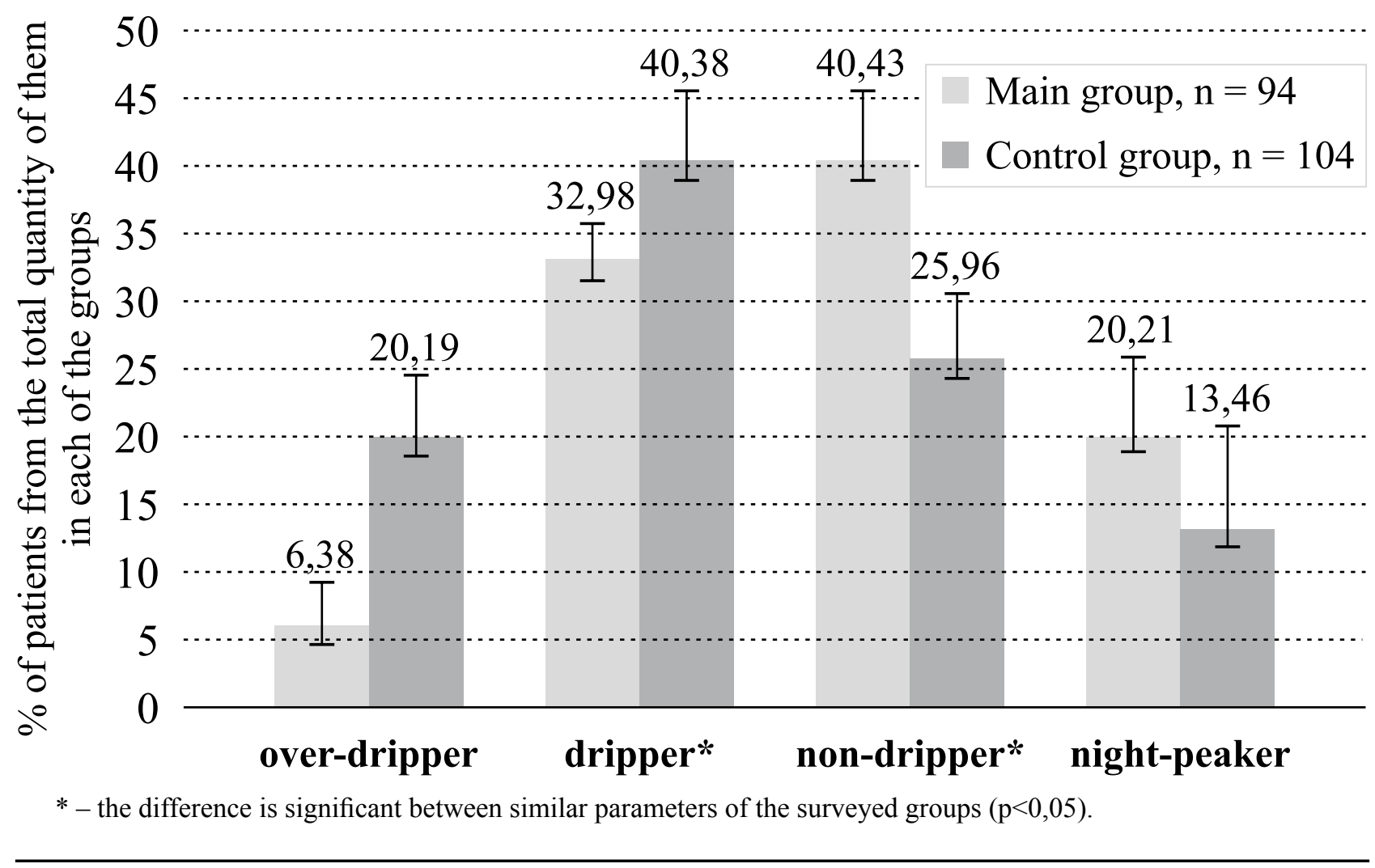


Table 5. Parameters of 24-h HR monitoring $(\mathrm{M} \pm \sigma)$

\begin{tabular}{|l|c|c|c|c|c|c|}
\hline \multirow{2}{*}{ Parameter } & \multicolumn{2}{|c|}{ Daytime } & \multicolumn{2}{c|}{ Nighttime } & \multicolumn{2}{c|}{ 24-h period } \\
\cline { 2 - 7 } & $\begin{array}{c}\text { Main } \\
\text { group, } \mathbf{n = 9 4}\end{array}$ & $\begin{array}{c}\text { Control } \\
\text { group, } \mathbf{n}=\mathbf{1 0 4}\end{array}$ & $\begin{array}{c}\text { Main } \\
\text { group, } \mathbf{n}=\mathbf{9 4}\end{array}$ & $\begin{array}{c}\text { Control } \\
\text { group, } \mathbf{n}=\mathbf{1 0 4}\end{array}$ & $\begin{array}{c}\text { Main } \\
\text { group, } \mathbf{n = 9 4}\end{array}$ & $\begin{array}{c}\text { Control } \\
\text { group, } \mathbf{n}=\mathbf{1 0 4}\end{array}$ \\
\hline HRmean & $77,1 \pm 12,5$ & $77,3 \pm 8,7$ & $61,8 \pm 7,9^{*}$ & $65,8 \pm 4,0$ & $74,1 \pm 12,5$ & $74,8 \pm 7,3$ \\
\hline HRmin & $61,7 \pm 10,0$ & $59,5 \pm 6,7$ & $54,3 \pm 9,2^{*}$ & $57,0 \pm 4,2$ & $56,6 \pm 11,3$ & $56,2 \pm 4,6$ \\
\hline HRmax & $105,8 \pm 15,9$ & $102,4 \pm 12,0$ & $74,6 \pm 9,0^{*}$ & $83,0 \pm 10,7$ & $104,3 \pm 15,0$ & $102,4 \pm 12,0$ \\
\hline HR sigma & $9,6 \pm 3,5$ & $8,8 \pm 2,4$ & $5,2 \pm 2,6$ & $6,8 \pm 3,1$ & $10,3 \pm 3,8$ & $9,8 \pm 2,9$ \\
\hline
\end{tabular}

* - the difference is significant between similar parameters of the surveyed groups $(\mathrm{p}<0,05)$.

pathoadrenal system. This vagal effect is most pronounced at nighttime during the circadian maximal activity of the parasympathetic nervous system. Under conditions of adequate regulation with increasing BP due to baroreceptors, there is a decrease in the tone of the sympathetic part of the autonomic nervous system and an increase in the tone of the parasympathetic one.

To analyze the presence of autonomic imbalance, the results of 24-h ECG monitoring were studied, namely: QTc interval and its variance. The obtained data on the studied groups are given in Table 6.

According to the results, there were significantly $(p<0,05)$ lower QTc $_{\text {min }}$ and greater QTc variance in the main group of patients relative to the control one, indicating the episodes of faster depolarization and repolarization of the ventricular myocardium, which lead to a faster contraction of cardiomyocytes myofibrils.

Thus, according to 24-h BPM and ECG monitoring, we can talk about the violation of the autonomic regulation of the cardiovascular system in patients after a hemorrhagic stroke. The very fact of a hemorrhagic stroke leads to a violation of autoregulation of cerebral circulation. But unstable autoregulation of cerebral circulation leads to hemorrhagic stroke, one of the factors of vi- olation of which is the factor of mild TBI in the anamnesis.

Hence, during the collection of anamnestic data, a significantly higher prevalence of mild TBI in the anamnesis was found among patients of the main group compared with the control one $-37,2 \%$ (35 patients out of 94 ) and 13,5\% (14 people out of 104), respectively, - which is reflected in Fig. 3.

As noted above, past TBI can lead to an autonomic imbalance with impaired normal BP regulation, which manifests itself in the years after the injury and potentially affects the risk of hemorrhagic stroke, at least in some patients.

\section{Discussion.}

According to the obtained results, the greater variability of BP in patients of the main group compared with the control may indicate a BP autonomic regulation disorder. A decreased parasympathetic tone has been described in individuals with a "non-dipper" daily BP profile (Radchenko, 2015), which is also associated with numerous chronic conditions, including the presence of autonomic dysfunction (Boyev et al., 2018), which occurs when comparing patients with hemorrhagic stroke and without it.

The signs of impaired regulation of BP were considered as the passage of an electrical impulse

Table 6. QTc values in the studied cohorts of patients $(\mathrm{M} \pm \sigma)$

\begin{tabular}{|l|c|c|}
\hline Parameter & Main group, $\mathbf{n = 9 4}$ & Control group, $\mathbf{n = 1 0 4}$ \\
\hline QTcmin & $286,28 \pm 43,34^{*}$ & $336,69 \pm 22,55$ \\
\hline QTcmean & $407,01 \pm 19,57^{*}$ & $412,50 \pm 17,23$ \\
\hline QTcmax & $518,83 \pm 28,53$ & $525,01 \pm 22,58$ \\
\hline QTc variance & $232,56 \pm 44,55^{*}$ & $188,31 \pm 33,67$ \\
\hline
\end{tabular}

* - the difference is significant between similar parameters of the surveyed groups $(\mathrm{p}<0,05)$. 
Figure 3. Prevalence of mild TBI in the anamnesis of individuals of the study groups.

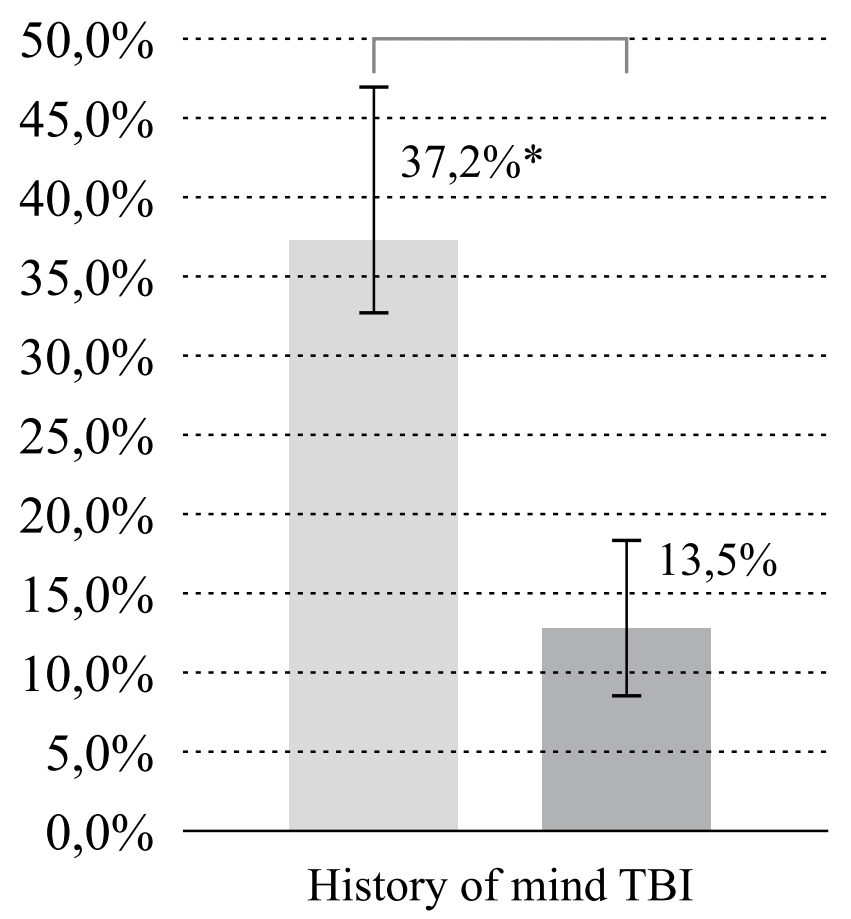

Main group, $\mathrm{n}=94$

Control group, $\mathrm{n}=104$

* - the difference is significant between similar parameters of the surveyed groups $(p<0,05)$.

through the ventricular myocardium- assessed by QTc. The reference range of the interval QTc is $320-440 \mathrm{~ms}$. The deviation from physiological norms of QTc interval duration is an important unfavorable clinical prognostic sign (Mal'ceva et al., 2014). The reduction in the QTc interval by adrenergic stimulation that alters autonomic balance is likely caused by the release of catecholamines during exertion (Pavão et al., 2014). One of the reasons for the transient form of the syndrome of the shortened QT interval, might be the autonomic nervous system tone disorder. The criteria for diagnosing the syndrome of the shortened QT interval is the duration of the QTc interval $<300 \mathrm{~ms}$ (Kovalenko, 2008).

A direct correlation between QTc variance and sympathetic system activity has been previously detected (Svitly'k, 2014). The recent data of the negative impact of increased QTc variance on the prognosis of cardiovascular disease were analyzed (Pustovojtova and Marty`m`yanova, 2012). QTc interval studies are already available in patients with hemorrhagic stroke (Malik et al., 2013). In that study, it was found that patients who had undergone a subarachnoid hemorrhage had a shortened $\mathrm{QTc}_{\min }$ index and a greater variance of QTc, which indicates increased reactivity of the vascular system to sympathoadrenal exposure.

Autonomic dysregulation occurs after brain damage. In the main group, $100 \%$ of patients had previously compromised background due to hemorrhagic stroke. However, some patients in the main group also had mild TBI before the hemorrhagic stroke incidence. This requires special attention in terms of prevention of the first stroke due to the significantly higher number of such patients in the main group in comparison to the control one. In addition, according to the World Health Organisation, the frequency of TBI is 1,85,4 cases per 100,000 population (Shkol'ny' $k$ et al., 2015). The overall incidence of mild TBI in individuals aged $16-59$ years is 302 per 100,000 person-years (281-324; 95\% confidence interval) (Skandsen et al., 2019), which is significantly lower than in the main group, according to the results of our study.

In individuals without a clinical manifestation of autonomic dysfunction but with a history of mild TBI, a decrease in total cardiovascular modulation at rest with a shift towards sympathetic rather than parasympathetic activity and a decrease in baroreflex response on orthostasis were found (Hilz et al., 2017).

These findings support the assumption that the slight dysfunction of the central autonomic network is explained by subclinical cardiovascular dysregulation, which is observed in patients even years after they received mild TBI (Hilz et al., 2017). Even mild TBI is responsible for the delayed reduction of "resistance" of the brain to various pathologies (Shkol`ny`k et al., 2015).

Autonomic nervous system dysfunction in the long-term perspective may even contribute to the increase in mortality observed in patients with a history of mild TBI. In these patients having no persistent neurological deficits and clinically significant autonomic dysfunction, there was 
a general decrease in autonomic cardiovascular modulation at rest with a shift to a greater sympathetic tone (Audrey and Procter, 2015). Individuals with a history of even mild TBI may have impaired autonomic modulation at rest and compromised efferent reactions of the baroreflex during exertion, as well as when the load on the baroreceptors has been stopped. Under normal conditions, this dysfunction does not appear to have clinical consequences. However, under certain circumstances or extremely heavy loads, this can lead to an autonomic dysfunction that can increase the cardiovascular risk in people with a history of TBI. In everyday life, it is impossible to avoid episodes of high stress, which can lead to autonomous regulation disorder. Therefore, researchers recommend screening for autonomic dysregulation of the cardiovascular system to identify a risk group for cardiovascular events or emotional and mental complications in patients with a history of mild TBI (Sung et al., 2016). Hilz MJ et al. concluded that the results of their research on autonomic and especially baroreflex dysfunction support the hypothesis that autonomic dysregulation may contribute to cardiovascular imbalance, which in turn increases the risk of cardiovascular events and, ultimately, death even in years after receiving TBI (Audrey and Procter, 2015). The results are particularly relevant today, given the combat activity in the eastern regions of Ukraine (Anti-Terrorist Operation, then Joint Forces Operation), when the shock wave causes contusions of different severity, the mild ones of which are often unrecognized.

Recent studies show that the syndrome of autonomic dysfunction was present in $60 \%$ of patients who received contusions during hostilities. At the same time, in $33,3 \%$ of cases, it was a vascular crisis (Shkol'ny'k et al., 2015). The obtained results indicate that there is a pronounced imbalance and desynchronization in the structures of the autonomic nervous system caused by the action of the blast wave on the higher autonomic centers in the acute period of mild contusion combat TBI (Gostra bojova kontuzijna cherepno-mozkova travma: patogenez, diagnosty`ka, likuvannya : [monografiya], 2018). In particular, among the patients in the main group, there were seven former servicemen with experience in military operations or participation at military firing ranges with the impact of the blast wave. The autonomic vascular dysfunction with vascular crisis is one of the two most common syndromes that deteriorate the quality of life after TBI (Shkol'ny'k et al., 2015).

Symptoms of damage of the autonomic nervous system are observed in $96 \%$ of people with TBI. (Gostra bojova kontuzijna cherepno-mozkova travma: patogenez, diagnosty'ka, likuvannya: [monografiya], 2018). Closed TBI caused by an explosive wave is accompanied by permanent autonomic disorders. Structural and functional insufficiency of suprasegmental structures occurs in in such patients in the acute period of closed TBI.

Kozlowski et al., Leddy et al. observed that patients with a history of concussion were found to have abnormal BP during dosed physical exercises. In these two studies, along with several others, it was found that dysfunction in autoregulation associated with a concussion can lead to exercise intolerance, which persists for much more time than 7-10 days after TBI (Esterov and Greenwald, 2017). At least in seven other published studies, the effects of brain injury on arteries and BP have been examined, and in all of them, evidence of impaired autoregulation were found. Compared to healthy people, the cardiovascular modulation of the autonomic nervous system was reduced (Esterov and Greenwald, 2017).

According to the results of our study and taking into consideration the literature data, it can be stated that patients with EH complicated by hemorrhagic stroke, according to both data of 24-h BPM with ECG monitoring and anamnestic data are more prone to autonomic dysregulation of the cardiovascular system, which probably increases risks of subsequent cerebrovascular events.

The week point of this study is that patients with intracerebral and subarachnoid hemorrhage were not studied separately. Secondly, the difference between patients with a history of mild TBI and those without it was not studied. On the other hand, a multi-stage model of patients division into subgroups according to the location of stroke, the volume of hemorrhage, the severity of the condition during the acute period of the 
cerebrovascular accident is needed which would require a larger number of patients. In addition, retrospectively, it would be difficult to establish what influenced the detected autonomic dysregulation to a greater extent - a history of the stroke or the TBI.

Summarizing the presented data, we can conclude:

1. The largest fluctuations of SBP in the group of patients with EH complicated by hemorrhagic stroke occur during the daytime period, which is detected by the daytime SBP sigma, delta SBP $(p<0,05)$. Significantly increased BP variability - SBP ARV and SBP sigma during the daytime - in patients of the main group indicate a higher risk of any EH-associated cardiovascular event and death.

2. Short-term rises in SBP contribute to a greater load on the cardiovascular system than a steadily elevated SBP, which was more common for the patients of the control group. This is reflected in a significantly higher SBP HI in individuals of the main group compared to the control.

3. In the main group there were significantly fewer "over-dipper" and more "non-dipper" patients compared to the control group. In the main group, the largest number of patients had daily “non-dipper" BP profile, which indicates a stronger trend to dysregulation in autonomic control of BP.

4. The higher QTc variance and lower values of $\mathrm{QTc}_{\text {min }}$, as well as higher values of $\mathrm{SBP}_{\max }$ during the daytime period in patients of the main group indicate a trend to impaired regulation of the cardiovascular system with periodic overreaction to sympathoadrenal activity during increased load on adaptive mechanisms.

5. Patients in the main group have a higher frequency of mild TBI in the anamnesis, which might be considered as one of the putative risk factors for hemorrhagic stroke due to impaired autonomic regulation of cerebral circulation after TBI occurrence.

Financing. This study did not receive external funding.

Conflict of interest. None of the authors received research grants, speaker's fees from any companies and is not a member of commissions.

Consent to publication. All authors have read and approved the final version of the manuscript. All authors have agreed to publish this manuscript.

\section{References:}

Антомонов М. Ю. (2017). Математическая обработка и анализ медико-биологических данных. Киев, Мединформ.

Audrey, S., Procter, S. Employers' views of promoting walking to work: a qualitative study. Int J Behav Nutr Phys Act 12, 12 (2015). https://doi.org/10.1186/s12966-015-0174-8

Avolio, A., Kim, M. O., Adji, A., Gangoda, S., Avadhanam, B., Tan, I., \& Butlin, M. (2018). Cerebral Haemodynamics: Effects of Systemic Arterial Pulsatile Function and Hypertension. Current hypertension reports, 20(3), 20. https://doi. org/10.1007/s11906-018-0822-x

Baldi, I., Azzolina, D., Berchialla, P., Gregori, D., Scotti, L., \& Corrao, G. (2017). Comorbidity-adjusted relative survival in newly hospitalized heart failure patients: A population-based study. International journal of cardiology, 243, 385-388. https://doi.org/10.1016/j.ijcard.2017.05.080

Боєв С.С., Доценко .Я., Шехунова І.О., \& Герасименко Л.В. (2018). Хронотерапія артеріальної гіпертонії: сучасний стан питання. Артериальная гипертензия, 6(62).

Clausen, M., Pendergast, D. R., Willer, B., \& Leddy, J. (2016). Cerebral Blood Flow During Treadmill Exercise Is a Marker of Physiological Postconcussion Syndrome in Female Athletes. The Journal of head trauma rehabilitation, 31(3), 215-224. https://doi.org/10.1097/HTR.0000000000000145

Esterov, D., \& Greenwald, B. D. (2017). Autonomic Dysfunction after Mild Traumatic Brain Injury. Brain sciences, 7(8), 100. https://doi.org/10.3390/brainsci7080100

Fauci, A. S. (2015). Harrison's principles of internal medicine. McGraw-Hill Education. /Citations pp. 4660-4661/.

Глушко, А. В., \& Литвиненко, Н. В. (2016). Клініко-гемостазіологічні характеристики в дебюті геморагічного інсульту. Актуальні проблеми сучасної медицини: Вісник української медичної стоматологічної академії, $16(2$ (54)). 
Hilz, M. J., Wang, R., Markus, J., Ammon, F., Hösl, K. M., Flanagan, S. R., Winder, K., \& Koehn, J. (2017). Severity of traumatic brain injury correlates with long-term cardiovascular autonomic dysfunction. Journal of neurology, 264(9), 1956-1967. https://doi.org/10.1007/s00415-017-8581-1

Iimuro, S., Imai, E., Watanabe, T., Nitta, K., Akizawa, T., Matsuo, S., Makino, H., Ohashi, Y., \& Hishida, A. (2015). Hyperbaric area index calculated from ABPM elucidates the condition of CKD patients: the CKD-JAC study. Clinical and experimental nephrology, 19(1), 114-124. https://doi.org/10.1007/s10157-014-0965-2

Jaeger, M., Soehle, M., Schuhmann, M. U., \& Meixensberger, J. (2012). Clinical significance of impaired cerebrovascular autoregulation after severe aneurysmal subarachnoid hemorrhage. Stroke, 43(8), 2097-2101. https://doi. org/10.1161/STROKEAHA.112.659888

Kirkpatrick, L. A., \& Feeney, B. C. (2014). A simple guide to IBM SPSS: for version 22.0. Nelson Education.

Koide, M., Ferris, H. R., Nelson, M. T., \& Wellman, G. C. (2021). Impaired cerebral autoregulation after subarachnoid hemorrhage: a quantitative assessment using a mouse model. Frontiers in Physiology, 12, 710. https://doi.org/10.3389/ fphys.2021.688468

Коваленко В.Н. (2008). Керівництво по кардіології, 1424.

Ma, H., Guo, Z. N., Sun, X., Liu, J., Lv, S., Zhao, L., Guo, W., Jin, H., \& Yang, Y. (2017). Hematoma volume is a predictive factor of disturbed autoregulation after spontaneous intracerebral hemorrhage. Journal of the neurological sciences, 382, 96-100. https://doi.org/10.1016/j.jns.2017.09.035

Malik, S., Abdul Sattar, R., Shah, S., Rehman, H., Tahira, \& Ismail, M. A. (2013). Frequency of QTe prolongation in patients with hemorrhagic stroke. Journal of Ayub Medical College, Abbottabad : JAMC, 25(3-4), 75-77.

Мальцева, М. С., Волков, Д. С., ГунаєваКручина, О. О., \& Яблучанський, М. І. (2014). Клас тривалості інтервалу QTc і функціональні показники кровообігу в пацієнтів у гострий післяопераційний період у різних режимах електрокардіостимуляції. Медицина транспорту України, (2), 40-46.

Mena, L. J., Felix, V. G., Melgarejo, J. D., \& Maestre, G. E. (2017). 24-Hour Blood Pressure Variability Assessed by Average Real Variability: A Systematic Review and Meta-Analysis. Journal of the American Heart Association, 6(10), e006895. https://doi.org/10.1161/JAHA.117.006895

Pavão, M. L. R. C., Ono, V. C., Arfelli, E., Simões, M. V., Marin Neto, J. A., \& Schmidt, A. (2014). Morte Súbita Cardíaca e Síndrome do QT Curto. Arquivos Brasileiros de Cardiologia, 103(3), e37-e40. DOI: 10.5935/abc.20140133

Пустовойтова, Н. И., \& Мартимьянова, Л. А. (2012). Значение продолжительности интервала QТ ЭКГ у пациентов с артериальной гипертензией. Вестник Харьковского национального университета имени ВН Каразина. Серия «Медицина», (23 (998)).

Радченко, А. Д. (2015). Современные аспекты контроля артериального давления: достаточно ли рутинного измерения?(часть і). Артериальная гипертензия, (1 (39)).

Школьник, В. М., Науменко, Л. Ю., Фесенко, Г. Д., Голик, В. А., \& Коваль, М. Є. (2015). Наслідки черепно-мозкової травми як причина інвалідності: проблеми експертизи. Вісник проблем біології і медицини, (2 (4)), $202-206$.

Skandsen, T., Nilsen, T. L., Einarsen, C., Normann, I., McDonagh, D., Haberg, A. K., \& Vik, A. (2019). Incidence of Mild Traumatic Brain Injury: A Prospective Hospital, Emergency Room and General Practitioner-Based Study. Frontiers in neurology, 10, 638. https://doi.org/10.3389/fneur.2019.00638

Sung, C. W., Lee, H. C., Chiang, Y. H., Chiu, W. T., Chu, S. F., Ou, J. C., Tsai, S. H., Liao, K. H., Lin, C. M., Lin, J. W., Chen, G. S., Li, W. J., \& Wang, J. Y. (2016). Early dysautonomia detected by heart rate variability predicts late depression in female patients following mild traumatic brain injury. Psychophysiology, 53(4), 455-464. https://doi.org/10.1111/ psyp. 12575

Світлик, Ю. О. (2014). Динаміка показників коригованого інтервалу QT і дисперсії інтервалу QT та їх прогностичне значення у пацієнтів з ішемічною хворобою серця на фоні епідуральної анестезії із застосуванням різних місцевих анестетиків. Медицина неотложных состояний, (6), 98-102.

Уніфікований клінічний протокол екстреної, первинної, вторинної (спеціалізованої), третинної (високоспеціалізованої) медичної допомоги та медичної реабілітації «Геморагічний інсульт (внутрішньо мозкова гематома, аневризмальний субарахноїдальний крововилив)». Наказ Міністерства охорони здоров'я України 17.04.2014 № 275.

Візір, В. А., Деміденко, О. В., Гончаров, О. В., \& Полякова, Г. В. (2018). Гіпертонічна хвороба. Вторинні артеріальні гіпертензії. Нейроциркуляторна дистонія. Модуль 2. Ч. 2.

Зозуля, А. І., \& Кіт, І. В. (2013). Геморагічний інсульт: етіологія, патогенез, клініка, лікування (огляд літератури). Ліки України, (8), 4-9.

Зозуля, І. С., Головченко, Ю. І., Зозуля, А. І., Онопрієнко, О. П., \& Волосовець, А. О. (2015). Основні принципи діагностики, формування діагнозу, лікування та профілактики мозкового інсульту. Український медичний часопис, (5), 34-38. 


\section{ОЦІНКА ПОРУШЕННЯ РЕГУЛЯЦЇ̈ СЕРЦЕВО-СУДИННОЇ СИСТЕМИ У ХВОРИХ ПІСЛЯ ПЕРЕНЕСЕНОГО ГЕМОРАГІЧНОГО ІНСУЛЬТУ ЯК УСКЛАДНЕННЯ ГІПЕРТОНІЧНОЇ ХВОРОБИ}

\section{Ткачишин Олександр}

Асистент кафедри пропедевтики внутрішньої медицини №1

Національний медичний університет імені О.О. Богомольця, кафедра пропедевтики внутрішньої медицини № 1 Київ, Україна

Анотація. Метою дослідження було порівняти показники артеріального тиску та електрокардіограми, оцінені за їх добовим моніторуванням, та анамнестичні дані щодо перенесеної легкої черепно-мозкової травми між групою хворих на гіпертонічну хворобу через $\geq 6$ міс. після перенесеного геморагічного інсульту та групою хворих на гіпертонічну хворобу без ускладнень. Матеріали і методи. Загальна кількість обстежених хворих склала 198 осіб, які були поділені на 2 групи: основна $(\mathrm{n}=94$; вік - 54,4 $\pm 8,8$ років, $\mathrm{M} \pm \sigma)$ та контрольна ( $\mathrm{n}=104$; вік $-53,7 \pm 8,9$ років). Хворі основної групи перенесли геморагічний iнсульт як ускладнення гіпертонічної хвороби $\geq 6$ міс. тому. У контрольну групу потрапили хворі на гіпертонічну хворобу, стадія II. В обох групах хворих визначали показники добового моніторування артеріального тиску та електрокардіограми. Результати. Показники добового моніторування артеріального тиску в основній групі та контрольній, відповідно: середній систолічний артеріальний тиск вдень $109,6 \pm 1,6$ та $121,1 \pm 1,1$ мм рт. ст., мінімальний - 74,4 $\pm 2,0$ та $82,3 \pm 12,5$ мм рт. ст., максимальний $-168,2 \pm 1,9$ та $161,9 \pm 1,7$ мм рт. ст., $\mathbf{p}<0,05$. Показники сігма систолічного артеріального тиску вдень $(17,9 \pm 0,6)$ та його середньої реальної варіабельності $(11,31 \pm 0,26$ мм рт. ст.) були більшими в основній групі $(\mathrm{p}<0,05)$. Показник гіпербаричного навантаження систолічного артеріального тиску вдень був більшим в основній групі і становив 403,6 $\pm 25,9$ проти $231,7 \pm 12,1$ мм рт. ст. ×год у контрольній $(p<0,05)$. Середня, мінімальна та максимальна частота серцевих скорочень вночі була достовірно меншою в основній групі ( $<<0,05)$. Показник QTc ${ }_{\text {min }}$ був достовірно меншим в основній групі на відміну від контрольної - 286,28 $\pm 43,34$ та $336,69 \pm 22,55$,

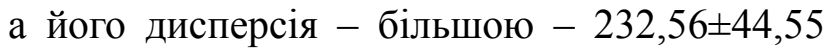
та 188,31 $\pm 33,67 \quad(\mathrm{p}<0,05) .3$ анамнестичних даних було виявлено достовірно більшу поширеність перенесеної в минулому легкої черепно-мозкової травми в основній групі - у 37,4\% (35 хворих з 94) - відносно контрольної (13,5\% (14 осіб зі 104)), $\mathrm{p}<0,05$. Висновки: Результати дослідження вказують на більший діапазон варіабельності артеріального тиску у пацієнтів з гіпертонічною хворобою, ускладненою геморагічним інсультом, яка може бути спричинена порушенням авторегуляції згідно 3 даними інтервалу QTс. У поєднанні з порушеннями мозкового кровообігу, спричиненими ушкодженням головного мозку внаслідок геморагічного інсульту окремо або в поєднанні з легкою черепно-мозковою травмою в анамнезі, такий стан показників може призвести до розвитку повторного інсульту.

Ключові слова: авторегуляція мозкового кровообігу, геморагічний інсульт, гіпертонічна хвороба, добове моніторування артеріального тиску та електрокардіограми, легка черепно-мозкова травма. 